Jan Kopiec, Zainteresowanie prof. Wojciecha Marii Bartla historia Kościota, [w:] Profesor Wojciech Maria Bartel w stużbie Kościotowi i Ojczyźnie, red. Andrzej Wójcik, Kraków 2019, s. 53-61.

DOI: http://dx.doi.org./10.15633/9788374387422.04

bp Jan Kopiec

Uniwersytet Opolski

\title{
Zainteresowanie prof. Wojciecha Marit Bartla HISTORIĄ KOŚCIOŁA
}

Wojciech Maria Bartel - krakowianin z urodzenia, wychowania i wykształcenia, mający także szczęście realizowania swego życiowego programu w swoim rodzinnym, królewskim mieście, owianym wspaniałą przeszłością i bogactwem kultury, budował bardzo konsekwentnie swą tożsamość i poczucie wartości. Wyrastał w klimacie ,sielsko-anielskim”, bowiem - jak sam przyznał w swych zapiskach pamiętnikarskich - nie brakowało mu nic, co by do szczęścia i zdrowia tak młodego obywatela potrzebne byłor. Korzystał obficie ze sprzyjających okoliczności, by chłonąć wiedzę, móc przyswajać języki obce, nawiązywać szerokie kontakty z wartościowymi ludźmi. Wprawdzie wnet wojna wiele zmieniła i zmusiła do trudnych decyzji, ale szczęśliwie młodego Bartla także wzmocniła i zahartowała. Po przejściu wojennej zawieruchy zo-letni Wojciech

I Por. „Ksiega mojego czasu i dziatañ”. Wojciech Maria Bartel I923-Ig92 w Io. rocznice śmierci. Katalog wystawy, Kraków 2002, s. 9. Do bogatszej zawartości notatek wspomnieniowych Wojciecha Bartla odwołuje się w biograficznym szkicu Janina Bieniarzówna: Wojciech Maria Bartel 1923-1992, w: Dawne prawo i myśl prawnicza. Prace historyczno-prawne poświęcone pamięci Wojciecha Marii Bartla, red. J. Malec, W. Uruszczak, Kraków I 995, s. 7-I 3. 
Maria Bartel świadomie wybrał studia prawnicze, $\mathrm{z}$ reguły w ocenie społecznej nobilitujące. I na tej drodze doszedł do najwyższych piedestałów i poszerzył grono zasłużonych dla naszych dziejów, co także ta konferencja, jak i poprzednie spotkania jemu poświęcone niewątpliwie potwierdzają. Ważne jest, że kierował się przekonaniem o przydatności wiedzy. Przyznał: „Już na pierwszym roku studiów zainteresowałem się problematyką historycznoprawną i uczestniczyłem w pracach seminarium poświęconego Konstytucji 3 maja prowadzonego przez Profesora Kutrzebę" . Już ten początek wskazywał, że w warsztacie przyszłego uczonego nie będzie brakowało - pośród badawczych problemów z dziedziny prawa tematów z zakresu historii, w czym Bartel upatrywał nieodzowne wsparcie dla formowania dojrzałego spojrzenia na ten aspekt ludzkiej egzystencji.

I. W jego przypadku przygoda z nauką mogła się zacząć od badania dziejów własnej rodziny i umacniania się dzięki temu w przyszłym profesorze świadomości starodawnych korzeni. Mogły napawać dumą przesłanki poświadczające przynależność wpisanego do metryk stanowych rodu do szlachty galicyjskiej; niebagatelna była też rola atmosfery religijnej w rodzinie, która sprzyjała zwłaszcza w Krakowie - odnoszeniu codziennej rzeczywistości do sfery religijnej i kościelnej. Dziś trudno nam przekonująco o tym ścisłym powiązaniu w jego osobistym życiu mówić bez powołania się na dokumenty, ale te okoliczności musiały w młodym i przenikliwym przedstawicielu rodziny Bartlów rozbudzić pytania natury historycznej, skłonić do zainteresowania się możliwościami ich zgłębiania i - by przywołać Leopolda von Rankego z jego słynnym zdaniem: „wie es eigentlich gewesen war” (zadaniem historyka jest szukać w każdym przypadku odpowiedzi na stawiany problem dziejowy, czyli zbadać, jak rzeczywiście było, a nie tylko, jak mu się wydaje, że było) - postawić sobie wyraźne pytania o fakty. By spróbować wniknąć w ten aspekt umysłowości Profesora, na-

2 J. Bieniarzówna, Wojciech Maria Bartel I923-1992..., dz. cyt., s. 17. 
leży uwzględnić w pierwszym rzędzie jego dorobek intelektualny, w czym pomocny jest precyzyjny przewodnik, czyli dorobek pisarski Wojciecha Bartla ujęty w zestawieniu bibliografii podmiotowej3. Widoczne jest aż nadto, że Bartel historykiem Kościoła sensu stricto nie był, ale przez całe swoje życie dawał wyraz świadomości, że otwierając jakąkolwiek kartę z przeszłości, trzeba na nią patrzeć holistycznie, całościowo, dostrzegając także oddziaływanie na dzieje społeczeństwa czynnika religijnego i kościelnego.

Towarzysząc Wojciechowi Bartlowi na jego drodze naukowej, spostrzegamy łatwo, że od początku swej samodzielnej pracy sięgał ambitnie do tematów trudnych i zgłębianie tematów dotyczących prawa łączył bardzo trafnie z drążeniem tematyki historycznej. A zainteresować go mogło w pierwszym rzędzie to, co miał na wyciągnięcie ręki w rodzinnym Krakowie, a co dotyczyło kluczowych spraw z dziejów ojczystych. Rozumiemy przez to w pierwszym rzędzie pozostające do dyspozycji badacza źródła, których Kraków jest prawdziwą skarbnicą, i na które młody uczony zwrócił uwagę.

Badając chronologicznie jego dorobek, zauważamy na podstawie przebadanego bogatego zasobu archiwaliów, że najwcześniej początkującego asystenta w Uniwersytecie Jagiellońskim zaintrygowała insurekcja kościuszkowska. Wiadomo, jaką rolę odegrał Kraków w życiu samego Tadeusza Kościuszki, jak też w zaplanowanym powstaniu narodowym, które miało obronić niepodległość chylącego się ku upadkowi państwa. Bartla zainteresować musiata nie tylko faktografia powstania, ale nade wszystko fundamenty ideowe tego wydarzenia. Już w 1954 roku pisał o dozorach w insurekcji kościuszkowskiej, w tymże samym roku podjął refleksję nad wątkami ustrojowymi obecnymi w programie kościuszkow-

3 Bibliografia prac prof. Wojciecha M. Bartla, zestawil P. Kuglarz, w: Dawne prawo..., dz. cyt., s. I 5-25. Korzystam z tego zestawienia dla usystematyzowania dorobku naukowego Profesora.

4 W. M. Bartel, Dozory w Insurekcji Kościuszkowskiej, „Czasopismo Prawno-Historyczne" 6 (1954) z. 2, s. 78-104. 
skim. Niedługo potem w obszernym studium, stanowiącym badawczy fundament dla jego dysertacji doktorskiej, omówił system władz cywilnych w tymże powstaniu ${ }^{6}$, dochodząc do bolesnego faktu kapitulacji królewskiego miasta ${ }^{7}$. Jeszcze później powrócił do badania związków Kościuszki z Krakowem, włączając w nie także reminiscencje rodzinne ${ }^{8}$. W podjęciu tak rozumianej tematyki ujawnia się przenikliwy zmysł badawczy, dzięki któremu nasza wiedza o tym dramatycznym zrywie ważnego bohatera narodowego, który pociągnął za sobą znaczny odsetek narodu, została istotnie wzbogacona o nowe wątki i dokumentację. Niemal jednocześnie z podjęciem powyższej problematyki uwagę przyszłego profesora przyciągnęło Wolne Miasto Kraków, w szczególności zaś rewolucja krakowska I846 roku, a to ze względu na jej wyjątkowo trudny kontekst dziejowy, jak też ciągle jeszcze niejednoznaczną ocenę jej charakteru. Ten fakt niezmiennie zmusza do drążenia tego dramatycznego wydarzenia metodą krytyki historycznej ${ }^{9}$. Bartel w świetle źródeł pogłębił rozumienie tego bolesnego dramatu dziejowego, ukazując go na szerszym tle koncepcji społeczno-politycznych utrzymujących się w społeczeństwie polskim po klęsce powstania listopadowego. To pozwoliło mu przeprowadzić trafną analizę stanu umysłów Polaków, zwłaszcza elit narodu dotkniętego przez zaborców represjami ${ }^{10}$. Kolejną próbę badania

5 W. M. Bartel, Elementy burżuazyjno-demokratyczne w ustroju Powstania Kościuszkowskiego, w: Zagadnienia prawne Konstytucji PRL, t. 2, Warszawa I954, s. 4I 9-448 (razem z J. Baszkiewiczem, W. Rostockim, W. Zienkiewiczem).

6 W. M. Bartel, Ustrój wtadz cywilnych powstania kościuszkowskiego, „Studia nad Historią Państwa i Prawa”, seria II, Wrocław i 959, ss. 247.

7 W. M. Bartel, Kapitulacja Krakowa w dniu Is czerwca 1794 r., w: Teki archiwalne, t. 9, Warszawa 1963, s. 1 05-I 2 I.

8 W. M. Bartel, O Kościuszce i jego spotkaniach z Krakowem, Kraków 1969 (Kraków dawniej i dziś, 19).

9 W. M. Bartel, Różne wersje aktów rewolucji krakowskiej I 846 r., „Kwartalnik Historyczny" 63 (1956) nr 2, s. 95-107.

I $\mathrm{W}$. M. Bartel, Rewolucja krakowska I 846 roku na tle niektórych polskich koncepcji spoteczno-politycznych lat I 83 I-I 846, „Czasopismo Prawno-Historyczne” 9 ( I 957 ) z. I, s. I 3 I-226. 
ustroju i struktury Wolnego Miasta Krakowa stanowi tekst referatu pt. „Zgromadzenie Reprezentantów Wolnego Miasta Krakowa”, przez co precyzyjniej można traktować o tym organizmie narodowym. W tym okresie bardzo ożywionej intelektualnej aktywności Wojciech Bartel sięgał do późniejszych, także trudnych, problemów dziejów Polski w okresie zaborów. Wiele badawczych impulsów podsunęło mu efemeryczne Księstwo Warszawskie, istniejące z nadania Napoleona w latach I807-I8I4. Przyglądnął się temu interesującemu tworowi politycznemu poprzez pryzmat ustawodawstwa stanowionego w warunkach braku pełnej niepodległości dawnego państwa. Ten, w sumie krótki, bo trwający zaledwie 8 lat epizod w tysiącletnich dziejach państwa i narodu polskiego zasługuje jednak na dalsze badania, a to głównie ze względu na formowanie się wówczas w Europie ducha nowej epoki, znaczonej dorobkiem myśli oświeceniowej. By móc przeanalizować ten fakt historyczny bardziej wszechstronnie, Bartel zajął się, razem z innymi specjalistami z tego zakresu, przygotowaniem bardzo pożytecznej czterotomowej edycji dokumentów o charakterze normatywnym, tworzących zręby ustrojowe tej namiastki państwowości polskiej ${ }^{12}$. Znaczący wysiłek naukowy, związany z przygotowaniem obszernego materiału (łącznie 920 stron druku) wprowadził Wojciecha Bartla do grona wytrawnych uczonych i znawców nie tylko prawa, ale też mechanizmów dziejowych tego okresu ${ }^{13}$. Przyznać należy, że ta publikacja bez wątpienia należy do znaczących osiągnięć z dziedziny prawa, ale bez myślenia historycznego trudno byłoby zrealizować tak ambitny temat. Na wszystkich etapach tego aktywnego postępo-

I I Opublikowany w: „Czasopismo Prawno-Historyczne” 36 (I 984 ) z. I, s. I 43 I 53 .

I 2 Ustawodawstwo Księstwa Warszawskiego. Akty normatywne wtadzy najwyż$s z e j$, t. I $1807-1808$, t. $21808-1810$, Warszawa 1964 ; t. $318 I I-I 8 I 2$, Warszawa

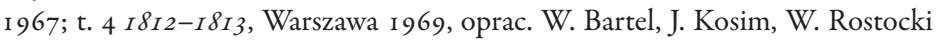
(Starodawne Prawa Polskiego Pomniki, seria 2: Pomniki Prawa Polskiego).

I 3 O docenianiu przez Bartla edycji źródłowych świadczy też wartościowy Wybór tekstów źródtowych do ćwiczeń z powszechnej historii państwa i prawa, Kraków 1967 (razem z I. Malinowską i S. Salmonowiczem). 
wania badawczego Wojciech Bartel bardzo dyskretnie dawał odczuć, zwłaszcza w tzw. epoce minionej, że w życiu narodu polskiego nigdy nie zabrakło odniesień do sfery religijnej.

2. Z pewnością podniesione zostanie $\mathrm{w}$ innych przedłożeniach kolejne, niezwykle ważkie zainteresowanie się Wojciecha Bartla pod wpływem profesora Michała Patkaniowskiego - zagadnieniami dotyczącymi dorobku cywilizacyjnego Anglii. Warto uświadomić sobie, że swe kompetentne badanie tematów angielskich podjął już na samym początku swej aktywności pisarskiej: jeszcze w 1946 roku jako młody student prawa opublikował krótki tekst o koordynacji nauki i przemysłu w Zjednoczonym Królestwie ${ }^{14}$, pogłębiając zagadnienie rok później omówieniem angielskich rozwiązań w dziedzinie nauki ${ }^{15}$. Stypendium uzyskane z British Council i możliwość nieco dłuższego wyjazdu w roku akademickim I960196I do Londynu celem pogłębienia swej wiedzy, zaowocowały pracą habilitacyjną, poświęconą ochronie wolności osobistej we wczesnośredniowiecznej Brytanii ${ }^{16}$. Nie trzeba uzasadniać, jakiego wysiłku wymagało już samo postawienie problemu badawczego, a jeszcze bardziej wymagające okazało się skompletowanie niezbędnej bazy źródłowej, by w końcowym efekcie dokonać wysiłku badawczego, łącznie z osadzeniem postawionej tezy na tle porównawczym, z wykorzystaniem materiałów. W tym przypadku przyswojenie wiedzy o wczesnych dziejach średniowiecznej Brytanii było więcej niż niezbędne. Nie tylko w tym przypadku Wojciech Bartel zabierał głos, uwzględniając uwarunkowania postrzegane rozwojowo, czyli historycznie, a także klimat duchowy chrześcijaństwa brytyjskiego w tej fazie jego dziejów. Dlatego też to dzie-

I 4 W. M. Bartel, Wspótpraca nauki i przemystu w Wielkiej Brytanii, „Życie Nauki” 2 (I946) nr I I-I 2, s. 46 I-464.

is W. M. Bartel, O centralnej Radzie Badań Naukowych $i$ innych angielskich projektach, „Życie Nauki” 3 (1947) nr I 5-16, s. 252-255.

I 6 W. M. Bartel, Ochrona wolności osobistej na tle rozwoju państwowości anglosaskiej Brytanii (do roku I o66), „Zeszyty Naukowe Uniwersytetu Jagiellońskiego. Prace prawnicze", z. 23, Kraków I 965. 
ło zostało uznane przez znawców problematyki za pionierskie nie tylko w literaturze polskiej, ale także angielskiej ${ }^{17}$.

Zresztą to nastawienie będzie towarzyszyło Wojciechowi Bartlowi właściwie przez całe życie. Trudno zdecydować, czy tylko właściwości metody nauk prawnych charakteryzowały jego szerokie badania nad kolejnym tematem, którym okazały się dzieje Wydziału Teologicznego Uniwersytetu Jagiellońskiego, w którego ramach pozostawała Katedra Prawa Kanonicznego. Wiadomo o XIV-wiecznej genezie uniwersyteckiej obecności w Krakowie; w XV wieku zawitała tam także teologia, uprawiana pod patronatem instytucjonalnego Kościoła. Wszystkie prace traktujące o uniwersytecie, tej dostojnej instytucji akademickiej stołecznego Krakowa, wymagały dobrej znajomości kontekstu dziejowego państwa i Kościoła, w jakim działał krakowski Wydział Teologiczny, a powstawały w ramach żywej współpracy z krakowskim Papieskim Wydziałem Teologicznym, późniejszą Papieską Akademią Teologiczną (obecnie Uniwersytet Papieski Jana Pawła II) ${ }^{18}$.

W tym nurcie powiązań dziejów z Kościołem znalazły swe miejsce kolejne pogłębione refleksje z dużym ładunkiem myślenia historycznego, zakładającego właściwe rozumienie Kościoła w dziejach narodu i jego kultury. Zawarł je Wojciech M. Bartel w takich opracowaniach, jak np. Materiaty źródtowe do sprawy biskupa Eętowskiego z lat I847-I849 ${ }^{19}$, O pracach naukowych ks. Alfonsa Schletza ${ }^{20}$ czy Naukowy mecenat Adama Stefana Sapiehy ${ }^{21}$. Te opracowania należały do specyficznego gatunku naukowego pisarstwa, jakim jest - najogólniej ujmując - biografistyka. Nie ulega wątpliwości, że niezależnie od merytorycznej problematyki w rekonstrukcjach biografii konkretnych osób zawsze musi być stosowana metoda

\footnotetext{
I 7 J. Bieniarzówna, Wojciech Maria Bartel I 923-I992..., dz. cyt., s. 9.

I 8 Prawie wszystkie publikowane na łamach „Analecta Cracoviensia”; omawia je J. Bieniarzówna, Wojciech Maria Bartel I $923-$ I $992 . .$. , dz. cyt., s. I I-I 2.

I9 Opublikowane na łamach „Naszej Przeszłości” t. 36 ( I 97 I), s. 23 I-259.

20 W: „Nasza Przeszłość” t. 50 (1978), s. 27-4I.

2 I W: Księga sapieżyńska, t. I, red. J. Wolny, Kraków I 982, s. 205-24I.
} 
historyczna, gwarantująca poprawność merytoryczną. W tym zakresie Bartel dokonał bardzo wiele. Swą uwagę poświęcał nade wszystko osobom związanym ze środowiskiem polskich prawników, postaciom zasłużonym w różny sposób dla Krakowa; nie brakowało też w kręgu jego zainteresowań ludzi Kościoła, uczonych, hierarchów, odgrywających ważną rolę w społeczeństwie ${ }^{22}$. Był niezawodnym i kompetentnym współpracownikiem takich prestiżowych ośrodków biograficznych, jak redakcja ukazującego się w Krakowie Polskiego Słownika Biograficznego czy wiedeńskiego Österreichisches Biographisches Lexikon. Na kanwie rozważań biograficznych dotyczących poszczególnych osób formował się jego warsztat historyczny, który ułatwiał mu swobodne poruszanie się po wielu skomplikowanych i szeroko ujmowanych przez niego zagadnieniach z zakresu formowania się prawa i uprawiania tej dyscypliny na przestrzeni wieków ${ }^{23}$.

Niniejsze krótkie rozważania o warsztacie historycznym profesora Wojciecha Bartla ukazują, jak szeroka była panorama zagadnień, które podejmował jako zadania właściwe dla uczonego. W kręgu zagadnień, stanowiących dla niego wyzwanie badawcze, zawierały się takie tematy, jak np. władza polityczna, prawa człowieka, dzieje Kościoła, rozwój intelektualnych wątków w aktywności ludzkiej na przestrzeni wieków. Z upływem lat Bartel potrafił łączyć je w udaną syntezę, co było możliwe dzięki jego znajomości prawa

22 Por. J. Bieniarzówna, Wojciech Maria Bartel I923-1992..., dz. cyt., s. I I. J. Kopiec, Ludzie Kościota w naukowej biografii profesora Wojciech a Marii Bartla, w: Wojciech Bartel I923-1992. Materiaty z Posiedzenia Naukowego PAU w dniu is listopada 2002 r., s. 35-4 I (Archiwum Nauki PAN i PAU, I 2).

23 Na uwagę zasługuje też znacząca aktywność w pisaniu recenzji dzieł kanonicznych i dotyczących historii, w czym ujawnił się bez wątpienia format wybitnego uczonego. Nie można pominąć także ważnego aspektu naukowej działalności Bartla, jaką było dość częste omawianie periodyków naukowych, zwłaszcza zagranicznych; taki przegląd wyrabia wrażliwość na ważne nurty zainteresowań, także na arenie międzynarodowej. Warto jeszcze dodać, że Profesora żywo zajmowały kwestie związane z ruchem naukowym zarówno w Polsce, jak i za granicą - to wątek zasługujący na osobne opracowanie. 
i mentalności prawniczej, osadzonych z reguły na szerokim tle dziejowym. Tu należy wymienić ważne teksty o miejscu religii w dziejach Polski od XVI do XX wieku²4, a nawet - niestety, opublikowane już po zgonie Profesora - udane syntetyczne rozważanie na temat kształtowania się relacji między Kościołem i państwem w okresie komunistycznym ${ }^{25}$.

Wątków dotyczących tematu niniejszego artykułujest znacznie więcej, niż zdołałem poruszyć. Nasuwa się w tym miejscu wniosek myślę, że wystarczająco udokumentowany - że badacz każdej dziedziny ludzkiej aktywności wie, że musi swe rozważania ujmować w kontekście historycznym, nie bagatelizując nigdy sfery religijnej i kościelnej. Wojciech Maria Bartel wybrał studiowanie prawa, ale poznawanie tej sfery ludzkiej aktywności łączył, niezależnie od uwzględnianego aspektu, z refleksją nad wypracowanymi w ciągu wieków zasadami. Tworzył w określonym klimacie polityczno-społecznym, pracę badawczą łączył z aktualnym zaangażowaniem w realizowanie szczytnych zamierzeń.

I uwaga na koniec: trzeba podkreślić, że Wojciech Bartel posiadał umiejętność prowadzenia pracy zespołowej, co w gronie uczonych nie zdarza się zbyt często! Niezwykła otwartość Profesora przełamywała wiele oporów, o czym mogę i ja zaświadczyć.

\footnotetext{
24 W. M. Bartel, The State and Christian Religions in Poland from the I6th to the 2oth Century, w: The Common Christian Roots of the European Nations. An International Colloquium at the Vatican, Florence 1983, s. 827-842.

25 Kirche und Staat in Polen in den Jahren 1944-1989, Nijmegen 1993, ss. 3 I.
} 
